\title{
SEBARAN GUA ARKEOLOGIS DI KECAMATAN \\ PALIYAN KABUPATEN GUNUNGKIDUL DENGAN MENGGUNAKAN ANALISIS TETANGGA TERDEKAT (NEAREST NEIGHBOURHOOD ANALYSIS)
}

\author{
Harry Octavianus Sofian \\ (Balai Arkeologi Palembang) \\ Email: harry.octa@gmail.com
}

\begin{abstract}
ABSTRAK
Kawasan karst Gunung Sewu telah menarik perhatian para arkeolog sejak zaman kolonial Belanda hingga saat ini. Salah satu kawasan karst terletak di Kecamatan Paliyan, Kabupaten Gunungkidul. Berdasarkan penelitian yang dilakukan oleh Harry Octavianus Sofian tahun 2007, setidaknya ada 11 gua dan ceruk yang berpotensi sebagai hunian purba. Tulisan ini akan membahas dan mencari pola sebaran gua dan ceruk yang berpotensi sebagai hunian purba di Kabupaten Paliyan dengan menggunakan Analisis Tetangga Terdekat (Nearest Neighbor Analysis) secara manual dan menggunakan Analisis Tetangga Terdekat yang ada pada perangkat lunak Arc View.
\end{abstract}

Kata kunci: Gunungkidul, Kabupaten Paliyan, gua, analisis tetangga terdekat, software arc view

\section{DISTRIBUTION ARCHAEOLOGICAL CAVES IN THE DISTRICT PALIYAN GUNUNGKIDUL USING NEAREST NEIGHBORS ANALYSIS}

\section{ABSTRACT}

Gunung Sewu karst area has attracted the attention archaeologists since the Dutch colonial era to the present. One of the karst area is located Paliyan District, Gunungkidul Regency. Based on research conducted by Harry Octavianus Sofian in year 2007, there were at least 11 caves and rockshelter as a potential residential dwelling. This paper will discuss and look for patterns of spatial distribution of caves and archaeological potential rockshelter as an ancient settlement in the District Paliyan using Nearest Neighbor Analysis (Analisis Tetangga Terdekat) manually and use Neighborhood Statistic analysis contained in the Arc View software.

Keywords: Gunungkidul, Paliyan District, caves, nearest neighbor analysis, arc view software 


\section{PENDAHULUAN}

Kawasan karst adalah suatu bentangalam yang secara khusus berkembang pada daerah berbatuan karbonat. Bentangalam ini terbentuk sebagai akibat proses pelarutan dan pengendapan yang terjadi selama waktu geologi tertentu. Proses ini antara lain menghasilkan gua, doline, uvala dan karren (Haryono 2004: 1-15). Gua yaitu deretan rongga, dan lorong bawah tanah yang terbentuk secara alami, cukup dimasuki oleh manusia, dan umumnya dibentuk oleh proses pelarutan pada batugamping. Gua juga dapat diartikan sebagai rekahan alami akibat pelarutan pada batugamping (Samudra 2001: 2).

Salah satu kawasan karst yang terbukti telah dihuni oleh manusia prasejarah sejak puluhan ribu tahun yang lalu adalah kawasan karst Gunung Sewu di pantai selatan Jawa bagian tengah. Karena itu, kawasan ini menarik untuk diteliti lebih jauh. Kawasan karst Gunung Sewu amat luas, dan tercakup dalam tiga wilayah propinsi, yaitu Daerah Istimewa Yogyakarta (Kabupaten Gunungkidul) di bagian barat, Jawa Tengah (Kabupaten Wonogiri) di bagian tengah, dan Jawa Timur (Kabupaten Pacitan) di bagian timur (Simanjuntak 2004: 12).

Untuk kawasan karst Gunung Sewu di bagian timur telah dilakukan penelitian arkeologis yang cukup intensif oleh Von Koeningswald pada tahun 1936 di Song Agung, di sisi timur Gunung Cantelan, Kabupaten Wonogiri. R.P. Soejono dan Basuki pada tahun 1954 menemukan alat-alat neolitik dan mesolitik saat melakukan ekskavasi di Song Terus, Kabupaten Pacitan. Tahun 1992 Truman Simanjuntak dan François Sĕmah melakukan survei penjajagan di daerah Punung dan melakukan ekskavasi di Song Keplek dan Gua Dono, Kabupaten Pacitan (Simanjuntak dkk 2004: 8-9).

Penelitian gua-gua prasejarah di kawasan Gunung Sewu di bagian barat baru dimulai sekitar tahun 1990-an, antara lain dilakukan oleh Tim PTKA Jurusan Arkeologi Universitas Gadjah Mada, Balai Arkeologi Yogyakarta, dan Pusat Penelitian Arkeologi Nasional. Laporan Survei Arkeologis Potensi Gua Kecamatan Tanjungsari oleh Tim PTKA Jurusan Arkeologi Universitas Gadjah Mada tahun 2003 sampai 2004 disebutkan bahwa 21 situs gua dan ceruk mempunyai potensi sebagai tempat hunian manusia prasejarah dari 45 gua yang tersebar di Kecamatan Tanjungsari (Tanudirjo 2003: 69). Penelitian di wilayah Ponjong oleh Tim PTKA Jurusan Arkeologi Universitas Gadjah Mada telah mensurvei 72 gua horisontal, di antaranya 14 buah gua mengindikasikan bekas hunian manusia purba, dan 2 gua sudah diekskavasi (Pradnyawan dkk. 2002).

Potensi sumber air di masing-masing zona atau kawasan di Kabupaten Gunungkidul berbeda-beda. Zona Cekungan Wonosari merupakan daerah yang paling banyak memiliki sumber air dibandingkan dua zona yang lain. Walaupun Kawasan Gunung Sewu memiliki curah hujan cukup tinggi $(2.000-2.500 \mathrm{~mm}$ per tahun), tetapi tidak banyak memiliki sumber air. Hal ini disebabkan oleh keadaan fisik tanah Kawasan Gunung Sewu yang kurang dapat menyimpan air. Air hujan yang jatuh ke 
permukaan tanah sebagian besar langsung masuk ke dalam tanah melalui doline atau cekungan, dan selanjutnya mengalir ke laut melalui sungaisungai bawah tanah. Sebagian air yang berhasil tertampung di dalam doline atau telaga hanya mampu bertahan untuk kurun waktu tertentu, kemudian menjadi kering pada musim kemarau (Fauzi. 2002: 31-32).

Telaga merupakan sumber air yang dimanfaatkan penduduk untuk keperluan sehari-hari seperti mencuci, mandi bahkan memandikan ternak. Terdapat beberapa telaga yang berada di Kecamatan Paliyan antara lain.

\begin{tabular}{|c|c|c|c|c|c|c|}
\hline \multirow{2}{*}{ No } & \multirow{2}{*}{$\begin{array}{l}\text { Nama } \\
\text { Telaga }\end{array}$} & \multirow{2}{*}{$\begin{array}{l}\text { Lokasi } \\
\text { Telaga }\end{array}$} & \multicolumn{2}{|c|}{ Koordinat UTM } & \multirow{2}{*}{$\begin{array}{l}\text { Luas } \\
\text { Telaga } \\
\text { (Ha) }\end{array}$} & \multirow{2}{*}{$\begin{array}{l}\text { Musiman/ } \\
\text { Sepanjang } \\
\text { tahun }\end{array}$} \\
\hline & & & $x$ & $\mathbf{Y}$ & & \\
\hline 1. & Jambeanom & $\begin{array}{l}\text { Desa } \\
\text { Karangasem }\end{array}$ & 447904 & 9109975 & 1,164 & $\begin{array}{c}\text { sepanjang } \\
\text { tahun }\end{array}$ \\
\hline 2. & Bromo & $\begin{array}{l}\text { Desa } \\
\text { Karangasem }\end{array}$ & 446889 & 9110266 & 1,014 & $\begin{array}{c}\text { sepanjang } \\
\text { tahun }\end{array}$ \\
\hline 3. & Namberan & $\begin{array}{l}\text { Desa } \\
\text { Karangasem }\end{array}$ & 446842 & 9111238 & 0,514 & $\begin{array}{c}\text { sepanjang } \\
\text { tahun }\end{array}$ \\
\hline 4. & Guwoklepu & $\begin{array}{l}\text { Desa } \\
\text { Karangasem }\end{array}$ & 448072 & 9113852 & 0,274 & $\begin{array}{c}\text { sepanjang } \\
\text { tahun }\end{array}$ \\
\hline 5. & Ngeringin & $\begin{array}{l}\text { Desa } \\
\text { Karangasem }\end{array}$ & 446987 & 9114011 & 0,241 & $\begin{array}{c}\text { sepanjang } \\
\text { tahun }\end{array}$ \\
\hline 6. & Klepu & Desa Giring & 450683 & 9108739 & 0,547 & $\begin{array}{c}\text { sepanjang } \\
\text { tahun }\end{array}$ \\
\hline 7. & Pengos & Desa Giring & 450980 & 9108233 & 0,934 & $\begin{array}{c}\text { sepanjang } \\
\text { tahun }\end{array}$ \\
\hline
\end{tabular}

Tabel 1: Telaga di Kecamatan Paliyan

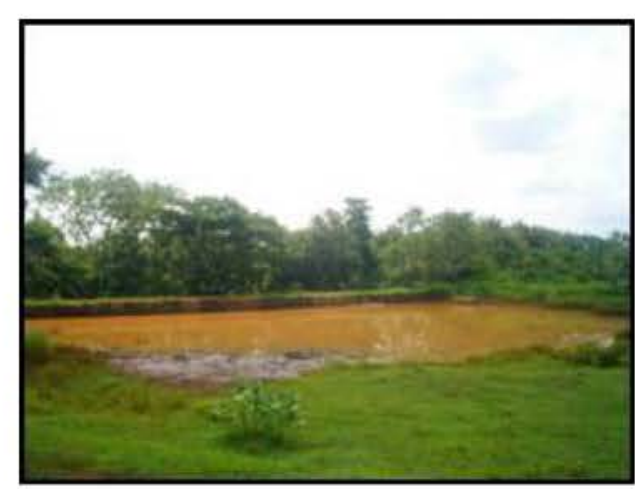

(foto 1)

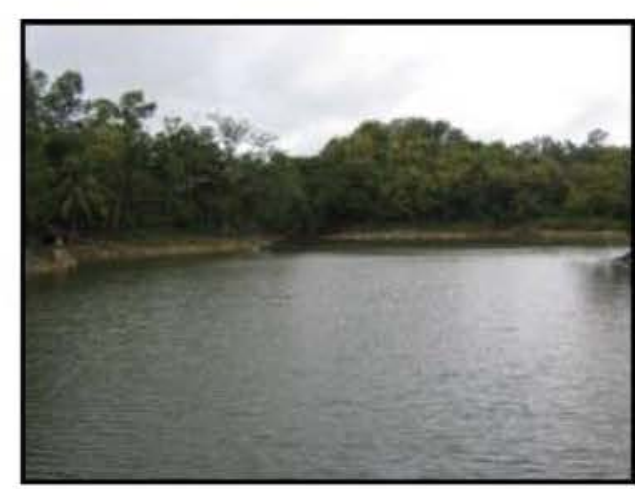

(foto 2)

Foto 1 dan 2: Telaga Guwolkepus (foto 1) dan Telaga Bromo (foto 2) di Desa Karangasem (sumber foto: pertulis)

Pengukuran Koordinat UTM telaga tersebut di atas hanya dilakukan pada satu titik, karena tujuannya hanya untuk mengetahui keletakan telaga secara umum saja. Untuk menghitung luas telaga penulis melakukan dijitasi pada peta RBI lembar Karangduwet dengan skala 1:25.000 dengan software Arc View, khususnya menerapkan aplikasi ekstension X-Tools. 
Untuk mengetahui telaga tersebut dapat menampung air pada periode tertentu saja atau dapat menampung air sepanjang tahun, penulis melakukan wawancara dengan penduduk desa tentang keberadaan telaga tersebut.

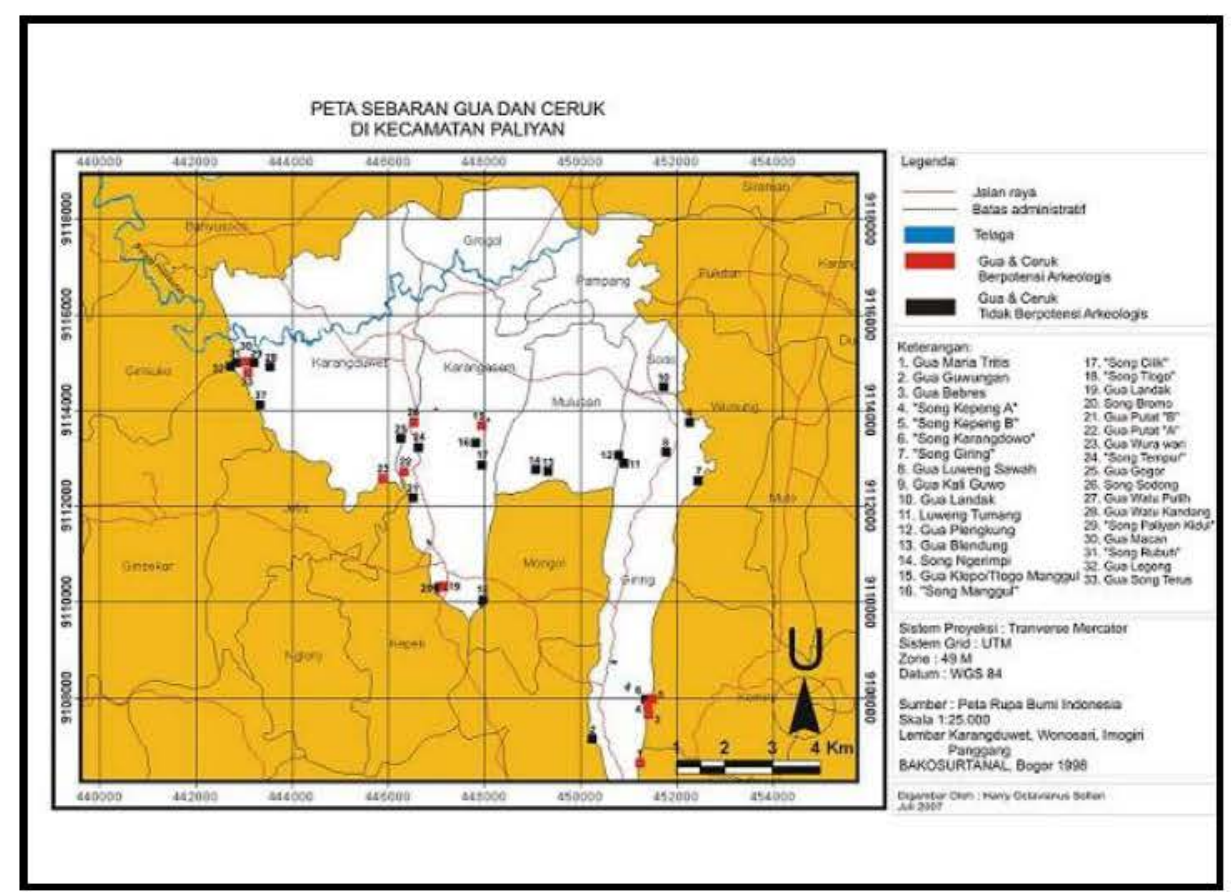

\section{Gambar 1: Peta sebaran gua dan ceruk di Kecamatan Paliyan (stumber gambar: penulis)}

Dari pengamatan yang dilakukan terhadap 33 gua dan ceruk yang ada di Kecamatan Paliyan, Kabupaten Gunungkidul, setidaknya terdapat 11 situs gua dan ceruk yang mempunyai potensi sebagai hunian manusia purba. Adapun gua dan ceruk yang berpotensi adalah sebagai berikut: Gua Maria Tritis, "Song Kepeng A", "Song Kepeng B", Gua Bebres yang terletak di Desa Giring, Gua Klepo/Tlogo Manggul, Song Sodong, Gua Landak, Gua Putat "A" yang terletak di Desa Karang Asem, Gua Wura Wari, Gua Song Terus, Gua Macan yang terletak di Desa Karang Duwet (Sofian. 2009: 31 45)

Tujuan yang ingin dicapai dari penelitian ini adalah mencari pola sebaran spasial gua dan ceruk yang berpotensi arkeologis sebagai hunian purba di Kecamatan Paliyan. Untuk menganalisis pola sebaran gua dan ceruk arkeologis, dilakukan dalam dua tahapan. Langkah pertama adalah menghitung indeks sebaran situs dengan menggunakan analisis tetangga terdekat (nearest neighbour analysis) secara manual. Langkah kedua, dilakukan dengan memanfaatkan analisis Neighboumood Statistic yang terdapat pada software arc view. 


\section{DESKRIPSI HASIL PENELITIAN}

\section{A. Metode Analisis Tetangga Terdekat (Nearest Neighbour Analysis)}

Untuk menganalisis pola sebaran gua dan ceruk arkeologis, penulis menggunakan metode analisis tetangga terdekat (Nearest Neighbour Analysis). Analisis ini merupakan salah satu analisis sebaran situs yang sangat populer di lingkungan arkeologi (Hodder dan Orton 1976: 35-52, Connoly dan Lake 2006: 164-166). Metode analisis tetangga terdekat dilakukan dengan cara melihat jarak antara satu situs dengan situs tetangga terdekatnya. Dengan cara analisis ini pola sebaran situs akan dapat ditentukan berdasarkan perhitungan derajat keacakannya (degree of randomnes). Cara ini dilakukan dengan melalui beberapa tahap. Adapun tahap-tahap yang dilakukan dengan metode ini adalah sebagai berikut. (lihat Hodder dan Orton 1976: 38-41, Connoly dan Lake 2006: 165).

1. Menentukan nilai rata-rata dari jarak yang diteliti (observed means) dengan rumus:

$$
\bar{r}_{0}=\frac{r}{n}
$$

adapun:

$r=$ Jumlah seluruh jarak dari situs-situs yang saling berdekatan

$\mathrm{n}=$ Jumlah situs yang digunakan sebagai sampel

2. Menentukan tingkat kepadatan situs dengan rumus:

$$
P=\frac{N}{A}
$$

adapun:

$\mathrm{N}=$ Jumlah keseluruhan situs yang diteliti

$A=$ Luas wilayah sebaran situs

3. Menentukan nilai rata-rata jarak situs yang diharapkan (expected means) dengan rumus:

$$
\bar{r}_{e}=\frac{1}{2 \sqrt{ } P}
$$

adapun:

$r \bar{e}=$ rata-rata jarak situs yang diharapkan

$\mathrm{P}=$ Tingkat kepadatan situs

4. Menentukan nilai hasil skala keacakan distribusi situs dengan rumus:

$$
r=\frac{\bar{r}_{0}}{\bar{r}_{\mathrm{e}}}
$$

$r=$ indeks penyebaran

5. Kriteria penggolongan pola persebaran adalah sebagai berikut:

$$
\begin{array}{ll}
r=0-0,9 & =\text { pola persebaran mengelompok; } \\
r=1-2,14 & =\text { pola persebaran acak; } \\
r=>2,15 & =\text { pola persebaran teratur. }
\end{array}
$$


Menurut Hodder, dalam analisis tetangga terdekat terdapat satu masalah yang sering muncul yaitu pada saat menentukan ukuran luas wilayah yang akan di analisis. Karena penentuan luas wilayah berdasarkan satuan batas administratif wilayah mengandung kelemahan dalam analisis ini sehingga kenampakan-kenampakan batas alam lebih diperhatikan dalam analisis ini. Jika satuan administratif tidak dapat digunakan, maka digunakan cara pembuatan batas persegi empat pada sisi-sisi terluar dari situs-situs yang diteliti, (Hodder dan Orton 1976: 30-33). Untuk lebih jelasnya dapat melihat gambar no. 2. Cara ini dapat dilakukan dengan pertimbangan bahwa pola keacakan sebaran situs seringkali dilihat pada bidang yang berbentuk segi empat (lihat juga Connoly dan Lake 2006: 163164, khususnya Fig 8.6 dan Fig. 8.7), apabila tidak dapat ditentukan batasan lingkungan alamnya. Dengan pertimbangan tersebut, luas wilayah penelitian di dalam analisis ini tidak lagi dibatasi dengan batas administratif. Batas-batas yang digunakan adalah wilayah berbentuk persegi yang ditentukan berdasarkan letak situs-situs yang terluar pada wilayah penelitian.

Pengukuran luas wilayah penelitian yang secara arbitrer ditentukan berbentuk bidang persegi empat pada sisi-sisi terluar dari situs yang diteliti dilakukan dengan menggunakan tool XTools, yang merupakan extension optional dari software Arc View. Kemampuan tool XTools ini adalah dapat mengukurkan area secara cepat dan akurat. Adapun caranya adalah sebagai berikut.

1. XTools termasuk extension optional, sehingga program Xtools dapat diaktifkan dengan mengkopi file extension XTools ke direktori program Arc View yang terletak di C:IIEsri |AV_GIS30 |ARCVIEW | EXT32.

2. proses aktivasi extension ini dengan menggunakan menu "File । Extensions" kemudian aktifkan check box "XTools6/1/01" dan tekan tombol "OK".

3. setelah diaktifkan, pengguna akan melihat pada objek "view" dengan "XTools" yang telah diimplementasikan ke dalam menu-bar berikut beberapa sub-menunya yang mencerminkan kemampuan dan fungsi yang dimiliki oleh extension yang bersangkutan.

4. tentukan dahulu pada menu pilihan untuk menentukan satuan luas wilayah, dalam penelitian ini dipilih satuan luas wilayah hektar $(\mathrm{Ha})$.

5. untuk menjumlahkan wilayah, klik "Tables" pada project dan klik "Select All" untuk memilih wilayah yang akan dijumlahkan.

6. kemudian klik menu XTools | Calculate Area, Perimeter, Length, Acres, Hectares.

7. jumlah perhitungan akan ditampilkan oleh menu "Display Selected Info" atau ikon

$\Sigma$

Adapun hasil penjumlahannya adalah $7.462,633$ Hectares. 


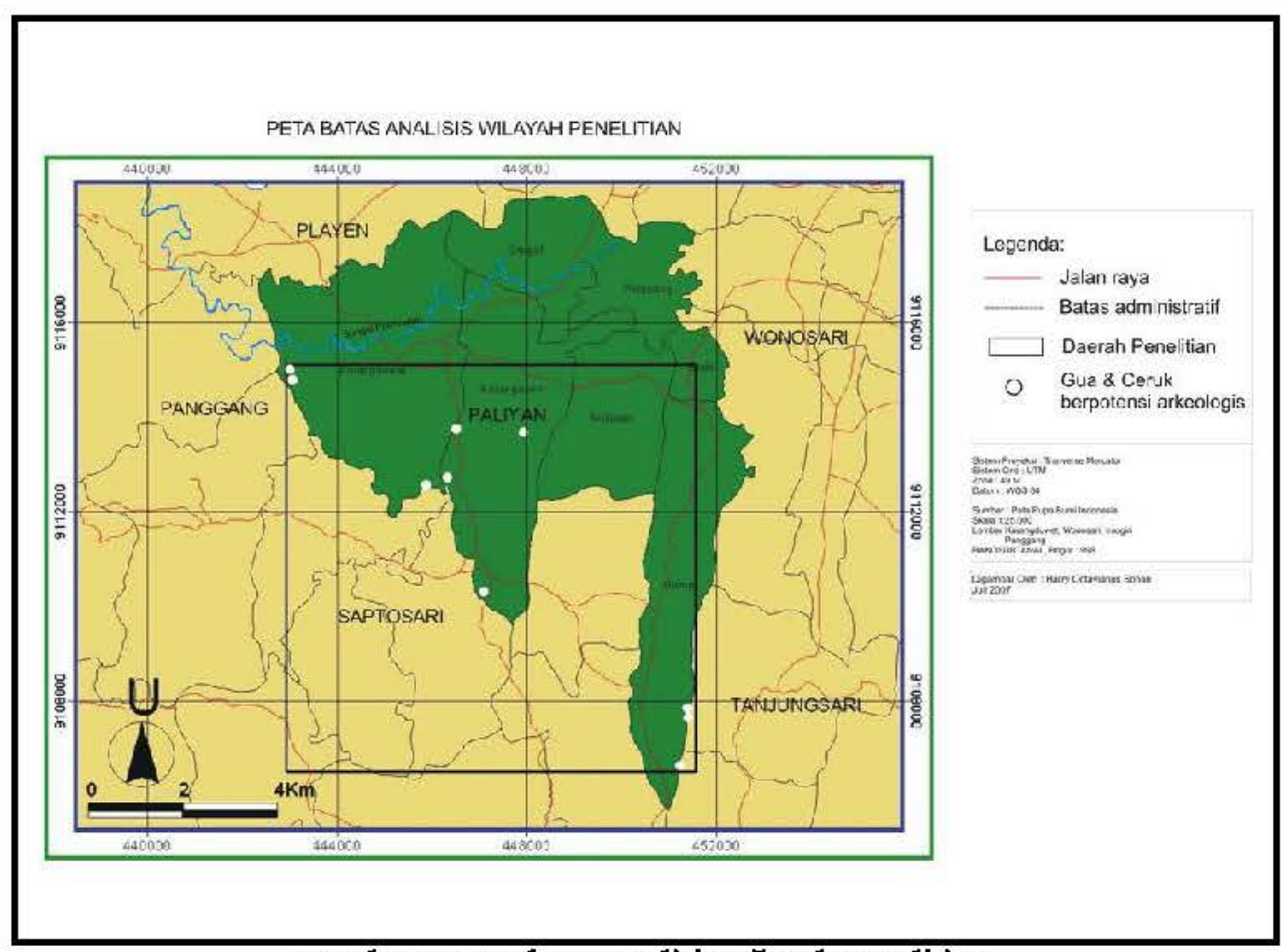

\section{Gambar 2: Peta batas analisis wilayah penelitian} (sumber gambar: penulis)

Selanjutnya, untuk pengukuran jarak antar masing-masing gua dan ceruk yang berpotensi arkeologis dilakukan menggunakan software Arc View. Penulis menggunakan tools measures dalam program Arc View dengan cara sebagai berikut.

1. Pada view, aktifkan file gua dan ceruk yang berpotensi arkeologis.

2. Setelah tampak pada view peta titik-titik gua dan ceruk yang berpotensi secara arkeologis, aktifkan tool measures distance dengan klik ikon

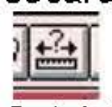

3. Setelah tool measures distance aktif, mulailah mengukur jarak titik-titik gua yang saling berdekatan, dengan cara mengklik titik di situs pertama dan seret ke titik situs kedua yang akan diukur jaraknya.

4. Setelah semua titik situs gua berpotensi diukur, lihat hasil pengukuran pada pojok kiri monitor komputer.

5. catat hasil pengukuran tersebut dan masukkan dalam tabel.

Dalam analisis ini, hasil pengukuran terlihat pada tabel berikut.

\begin{tabular}{|l|l|r|}
\hline No & Gua dan ceruk yang berpotensi arkeologis & Jarak (m) \\
\hline 1. & Gua Maria Tritis - Gua Bebres & 1.033 \\
\hline 2. & Gua Bebres - Song Kepeng B & 193 \\
\hline 3. & Song Kepeng B - Song Kepeng A & 6 \\
\hline 4. & Gua Tlogo Klepo/Tlogo Manggul - Song Sodong & 1.423 \\
\hline
\end{tabular}




\begin{tabular}{|l|l|r|}
\hline 5. & Song Sodong - Gua Putat A & 1.032 \\
\hline 6. & Gua Putat A - Gua Wura Wari & 477 \\
\hline 7. & Gua Wura Wari - Gua Landak & 2.559 \\
\hline 8. & Gua macan - Gua Song Terus & 223 \\
\hline Total jarak dalam meter & 6.959 \\
\hline \multicolumn{2}{|l|}{ Total jarak dalam Km } & 6,95 \\
\hline
\end{tabular}

Tabel 2: Jarak Gua dan Ceruk Dengan Tetangga Terdekat

Berdasarkan pengukuran yang sudah di lakukan di atas, indeks keacakan sebaran situs dapat dihitung mengkuti rumus yang telah ditetapkan di atas. Hasilnya dapat dilihat pada langkah-langkah penghitungan berikut ini.

1. Menentukan nilai rata-rata dari jarak yang diteliti (observed means).

$$
\begin{aligned}
\overline{r o} & =\frac{6,95 \quad \text { (tabel 5) }}{11 \quad \text { (jumlah gua dan ceruk yang berpotensi }} \\
& =0,63 \quad \text { arkeologis) }
\end{aligned}
$$

2. Tingkat kepadatan situs.

$$
\begin{aligned}
P & =\frac{11}{7.462,633} \\
& =0,00147
\end{aligned}
$$

3. Menentukan nilai rata-rata jarak situs yang diharapkan (expected means).

$$
\begin{aligned}
& \text { re }=\frac{1}{2 \sqrt{0.00147}} \\
& =1,57
\end{aligned}
$$

4. Menentukan nilai hasil skala keacakan distribusi situs:

$$
\begin{aligned}
r & =\frac{0,63}{1,57} \\
& =0,4012
\end{aligned}
$$

dengan hasil perhitungan $r=0,4012$ maka pola persebaran gua dan ceruk yang berpotensi arkeologis adalah cenderung mengelompok. 


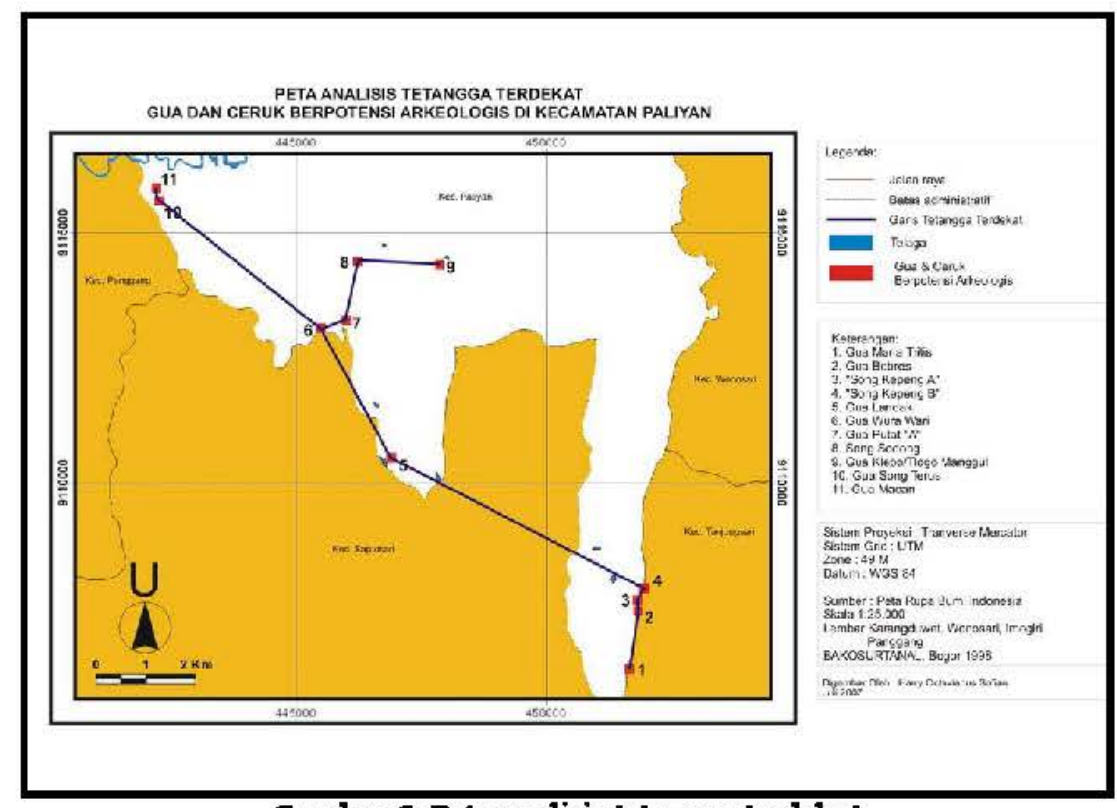

Gambar 3: Peta analisis tetangga terdekat (sumber gambar: penulis)

\section{B. Analisis Statistik Bertetangga (Neighbourhood Statistic)}

Hasil perhitungan manual di atas dapat ditegaskan kembali dengan menggunakan analisis Statistik Bertetangga pada software Arc View, yaitu dengan tools Neighbomood Statistics. Perintah ini juga bertujuan untuk mengetahui derajat keacakan. Namun demikian, analisis ini tidak lagi menampilkan angka-angka. Derajat keacakan langsung dapat diketahui dari sebaran situs pada peta yang ditunjukkan oleh lingkaran-lingkaran yang saling bertumpang tindih. Situs-situs dengan lingkaran yang bertumpang tindih dapat dikelompokkan menjadi satu kelompok, sedangkan situs-situs yang lingkarannya tidak bertumpang tindih berarti berada di kelompok lain. Adapun cara menggunakan tool Neighborhood Statistics adalah sebagai berikut.

1. Aktifkan view yang akan di analisis dengan menggunakan analisis ini.

2. Klik pada menu "Analyst" dan klik submenu "Neighbomood Statistics".

3. Tampilan di view merupakan hasil dari analisis ini.

Hasil analisis dari Neighborhood Statistics dapat dilihat pada gambar 4. 


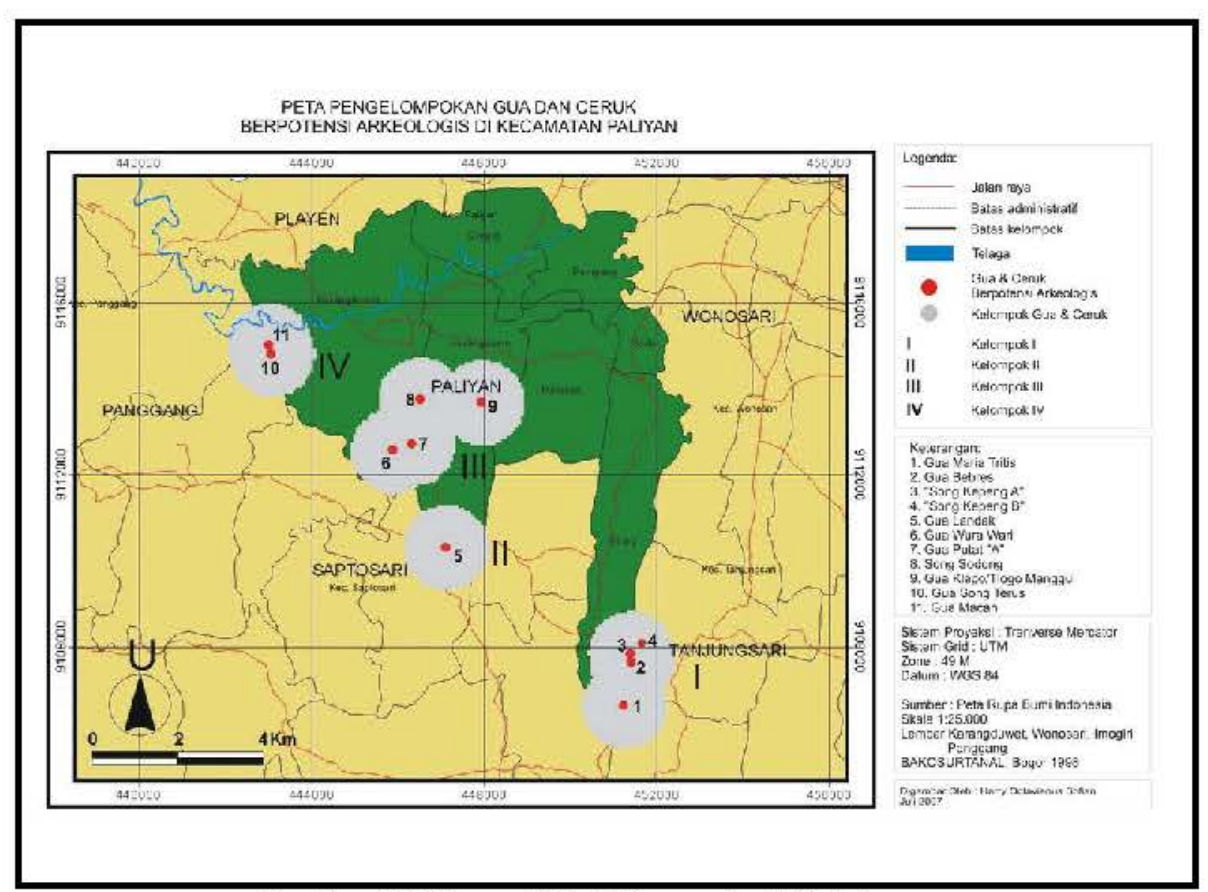

\section{Gambar 4: Peta aralisis tetangga terdekat dengan menggunatan software Are View (sumber gambar: penulis)}

Dari sebaran situs yang ditunjukkan gambar 4, terlihat bahwa gua dan ceruk yang berpotensi arkeologis di Kecamatan Paliyan cenderung mengelompok. Jadi, terdapat kesamaan hasil dari kedua analisis tetangga terdekat, baik yang menggunakan perhitungan secara manual maupun yang menggunakan bantuan software Arc View.

\section{KESIMPULAN}

Berdasarkan hasil Nearest Neighbour Analysis (analisis tetangga terdekat), baik yang menggunakan perhitungan secara manual maupun yang menggunakan bantuan software Arc View, setidaknya terdapat 4 kelompok gua-gua arkeologis di Kecamatan Paliyan yang cenderung mengelompok.

1. Kelompok Gunung Sewu bagian tengah I, dimana tempat hunian berada dekat dengan Wilayah Kecamatan Tanjungsari, seperti yang telah diteliti oleh Tanudirjo dkk pada tahun 2003.

2. Kelompok Gunung Sewu bagian tengah II, sebenarnya hanya berupa satu gua pada kecamatan Paliyan. Namun tidak menutup kemungkinan gua ini mengelompok dengan gua-gua di wilayah Kecamatan Saptosari yang diduga terdapat gua hunian yang berpotensi arkeologis. Untuk itu, perlu penelitian lebih lanjut di kecamatan tersebut. 
3. Kelompok Gunung Sewu bagian tengah III.

4. Kelompok Gunung Sewu bagian utara, yaitu kelompok gua-gua ini berada pada sisi utara Zona Gunung Sewu.

Adapun gua dan ceruk yang merupakan anggota masing-masing kelompok tersebut dapat dilihat pada tabel berikut.

\begin{tabular}{|l|l|l|c|}
\hline No & \multicolumn{1}{|c|}{ Kelompok } & \multicolumn{1}{|c|}{ Nama Gua } & $\begin{array}{c}\text { Jumlah } \\
\text { Gua dan } \\
\text { Ceruk }\end{array}$ \\
\hline 1. & $\begin{array}{l}\text { Kelompok Gunung Sewu } \\
\text { bagian tengah I }\end{array}$ & $\begin{array}{l}\text { Gua Maria Tritis, "Song } \\
\text { Kepeng A", "Song Kepeng } \\
\text { B", Gua Bebres }\end{array}$ & 4 \\
\hline 2. & $\begin{array}{l}\text { Kelompok Gunung Sewu } \\
\text { bagian tengah II }\end{array}$ & $\begin{array}{l}\text { Gua Klepo/Tlogo Manggul, } \\
\text { Song Sodong, Gua Putat } \\
\text { "A", Gua Wura Wari }\end{array}$ & 4 \\
\hline 3. & $\begin{array}{l}\text { Kelompok Gunung Sewu } \\
\text { bagian tengah III }\end{array}$ & Gua Landak & 1 \\
\hline 4. & $\begin{array}{l}\text { Kelompok Gunung Sewu } \\
\text { bagian utara }\end{array}$ & $\begin{array}{l}\text { Gua Song Terus, Gua } \\
\text { Macan }\end{array}$ & 3 \\
\hline \multicolumn{3}{|l|}{ Jumlah } & 11 \\
\hline
\end{tabular}

Tabel 3: Tabel Anggota kelompok gua dan ceruk yang berpotensi arkeologis

Yang menarik dari keempat kelompok gua dan ceruk yang berpotensi arkeologis ini, pada dua kelompok terdapat satu situs yang memiliki morfologi ruangan yang besar. Pada Kelompok Gunung Sewu bagian utara, Gua Song Terus memiliki ukuran ruang gua dengan panjang 5 $\mathrm{m}$ dan $30 \mathrm{~m}$, lebar $4 \mathrm{~m}$ dan $20 \mathrm{~m}$ dan tinggi $3 \mathrm{~m}$ dan $35 \mathrm{~m}$. Gua Song Terus memiliki 2 mulut gua, sehingga sangat tepat untuk tempat hunian. Pada Kelompok Gunung Sewu bagian tengah I, terdapat Gua Maria Tritis yang memiliki ukuran ruang gua dengan panjang $40 \mathrm{~m}$, lebar $35 \mathrm{~m}$ dan tinggi 40 $\mathrm{m}$. Diduga, kedua gua besar ini merupakan gua tempat hunian relatif menetap. Sebaliknya, di dua kelompok gua-dan ceruk lainnya yaitu Kelompok Gunung Sewu bagian tengah II dan Kelompok Gunung Sewu bagian tengah III tidak terdapat gua yang mempunyai ruangan besar. 


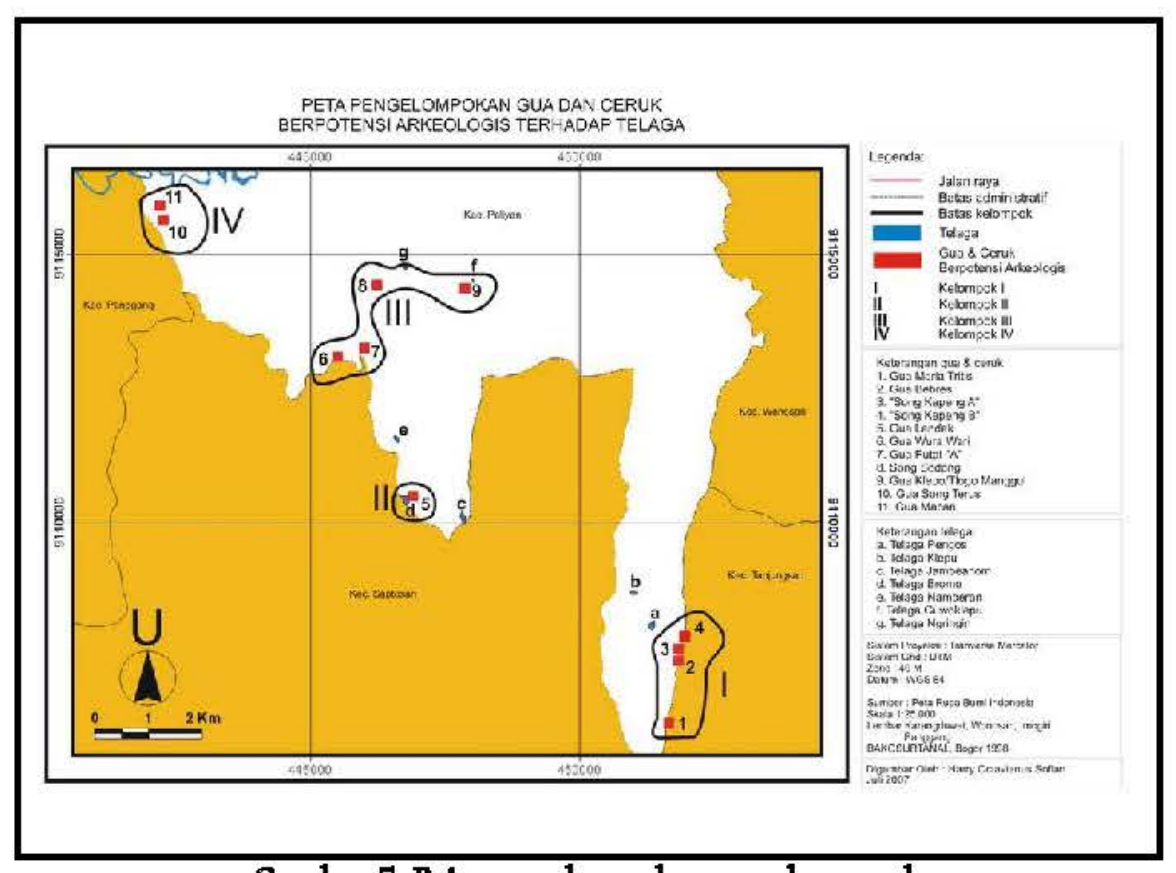

Gambar 5: Peta pengelorrpokan gua dan certk

berpotensi arkeologis terhadap telaga

(sumber gambar: penulis)

Untuk akses air sebagai sumber kehidupan, kelompok manusia purba yang menghuni Gunung Sewu bagian utara, dapat memanfaatkan sungai sebagai sumber air. Sungai yang masih mengalir sampai saat ini adalah Sungai Prambutan yang merupakan anak Sungai Kali Oyo atau bahkan Cekungan Wonosari sendiri merupakan sumber air. Kelompok manusia purba yang menghuni Kelompok Gunung Sewu bagian tengah I, II dan III diduga tidak memanfaatkan sungai sebagai sumber air, namun mereka memanfaatkan telaga sebagai sumber air karena faktor aksesibilitas dan jarak yang lebih dekat.

Terjadinya pola sebaran situs tersebut dapat disebabkan oleh berbagai macam faktor. Untuk wilayah penelitian di Kecamatan Paliyan pola sebaran mungkin lebih disebabkan oleh faktor lingkungan fisik (physical enviroment), yaitu berkaitan dengan keberadaan sumber daya air dan kenyamanan tempat tinggal. Mereka tidak akan menempati daerah yang miskin sumber makanan, tandus dan penuh bahaya, atau pun sulit diakses. Lingkungan sangat berperan penting pada masa itu, karena mereka belum mampu untuk mendomestifikasi binatang dan tumbuhan, sehingga jelaslah bahwa terdapat hubungan yang erat antara pola persebaran gua dan ceruk sebagai tempat bermukim dengan lingkungan, yaitu air dan makanan sebagai sumber kehidupan manusia. 


\section{KEPUSTAKAAN}

Connoly, James dan Mark Lake. 2006. Geographical Information Systems in Archaeology. Cambridge: Cambridge University Press.

Fauzi, Imam, 2002, Kronologi Penghunian Zona Cekungan Wonosan, Gunung Kidul: Kajian Berdasarkan Sebaran Situs dan Karakteristik Lingkungan. Skripsi Sarjana Fakultas IImu Budaya, Universitas Gadjah Mada.

Haryono, Eko \& Tjahyo Nugroho Adji. 2004. Pengantar Geomorfologi dan Hidrologi Karst, Yogyakarta, Kelompok Studi Karst Fakultas Geografi UGM.

Hodder, lan \& Clive Norton. 1976. Spatial Analysis In Archaeology. Cambridge: Cambridge University Press.

Pradnyawan, Dwi, dkk. (ed) 2002. Laporan Eksplorasi Potensi Budaya, Historis dan Arkeologis Ponjong 2002. Yogyakarta, PTKA Gunung Kidul - The Toyota Foundation, Jurusan Arkeologi, Fakultas IImu Budaya UGM.

Samodra, Hanang. 2001. Nilai Strategis Kawasan Karst Di Indonesia: Pengelolaan dan Penindungannya, Publikasi Khusus no.25, Bandung, Pusat Penelitian dan Pengembangan Geologi.

Simanjuntak, Truman, dkk. 2004. Prasejarah Gunung Sewu. Jakarta: IAAI.

Sofian, Harry Octavianus. 2009. Potensi Arkeologis Gua-Gua Di Kecamatan Paliyan Kabupaten Gunungkidul dalam Jurnal Arkeologi Siddhayatra No. 14 (1), Palembang: Balai Arkeologi Palembang.

Tanudirjo, Daud Aris, Anggraeni, Tjahjono Prasodjo. 2003. Potensi Gua-gua Sebagai Tempat Hunian Manusia Prasejarah Di Kecamatan Tanjungsari, Kabupaten Gunung Kidul, Daerah Istimewa Yogyakarta. Laporan Penelitian, Yogyakarta: Lembaga Penelitian UGM. 